the B type of forceps, with its smooth roller applied to the intact side of the conjunctiva, is used with much success in expressing the granules of the fornix without harming the palpebral conjunctiva. The author, therefore, wishes every practitioner may have these two of the forceps and take any one of them for the use of operation according to the condition of granules.

As for the author, his own way of expression of trachoma with his newly devised curved screw roller forceps is always accompanied by Kaining's massage and polishing of the conjunctiva with the glass rod. This method brings about many successful results. The curved screw roller forceps of Kanda is manufactured as well as sold by Handaya Medical Instruments Manufacturing Co., Tokio. It has been very successful in his hands and so the author believes no one can be disappointed by the use of this new type of curved screw roller forceps. (October 9, 1931.)

\title{
A SEVENTEENTH CENTURY LETTER DEALING WITH OPHTHALMIC MATTERS, ETC.
}

$$
\text { BY }
$$

\author{
R. R. JAMES \\ LONDON
}

A TRANSCRIPT of the letter here published was sent to me recently. It seems of sufficient interest to be printed in this journal.

Add. MS. 29244, fo. 10.

"Good Mr. Powers,

Because this affect proceedes from accidentall distemper rather than any naturall affluxion of humour, it had bene good to have opened a veyne, but nether $\mathrm{y}^{\mathrm{r}}$ yeares nor $\mathrm{y}^{\mathrm{s}}$ time of $\mathrm{y}^{\mathrm{e}}$ yeare are propitious, therefore if you find any disordered heates, I advise you to $y^{e}$ use of barly water made with liquerice anise seedes etc. I have directed you four thinges none not physicall as $\left(\mathrm{y}^{\mathrm{t}}\right.$ word is comonly taken) but only to rectify $\mathrm{y}^{\mathrm{r}}$ serous humour $\&$ voyd it by urine $w^{c h}$ is $y^{e}$ intention of $y^{e}$ pills to be taken at nights. I love no much tampering with thinges blowne into ye eye but now white sugar candy used as you mention can do no hurt. Therefore you may be bold wth it. I heare yor Dr there is much offended $w^{t}$ me for ... ying agt him. I pray stop ye rumor I assure you I have bene ever silent in ye censure of wandering practitionours \& so of him, but for a few words I inserted into a 
lettre to you, I suffre such to weary out themselves. I think him worthy of contempt not of opposition wch would make the world thinke there were something good in him $\mathrm{y}^{\mathrm{t}}$ might disadvantage me. Let him therefore not think of me, as I doe not of him, being neither sorry for his stay, nor glad for removall. This in haste $w^{\text {th }}$ my fond love.to you I rest,

$$
\text { yor very loving friend }
$$

John Symcottes.

Remember my service to Mrs Willis.

Dec: 20: 1636.

Bathe yor eyelidd, wth the water in the glasse oftentymes in the day, at $\mathrm{y}^{\mathrm{r}}$ pleasure and now and then you may dropp a dropp or 2 into $\mathrm{y}^{\mathrm{r}}$ eye especially to bedward and every night to bedward swallow doune 2 of the pills in the boxe, and soe rest.

And every morning fasting, and also about halfe an houre after meales, eate soe much of the powder in the paper as you can take up $w^{\text {th }}$ a shillinge.

Alsoe use yor we ointment yet somtymes, as before."

The writer of this letter was admitted, as John Symcotes, pensioner, at Queens' College, Cambridge, April, 1608. He was the son of John Simcotes, of Sutton, Beds. He matriculated in 1610 and took his B.A. in 1611/12; M.A., in 1615 and his M.D., from King's College, in 1636. His brother, who was also at Cambridge, became a parson and was Rector of a parish in Bedfordshire. The annotation notes are from Venn's Alumni Cantabrigienses, Vol. IV. I have not been able to find out when Dr. Simcotes died. Perhaps I ought to add that I have preserved the original orthography save in the word lettre, which I have extended from the formal contraction of the time.

\section{ANNOTATION}

\section{Instruction in the Treatment of Ophthalmia Neonatorum}

At the annual meeting of the British Medical Association held at Eastbourne in July, 1931, a resolution was carried drawing the attention of the General Medical Council to the present unsatisfactory state of the curriculum with regard to the teaching of the treatment of ophthalmia neonatorum to medical students.

It seems a pity that the facilities which exist at St. Margaret's Hospital should not be utilized for medical students in the same manner as they are for pupil midwives; but it is a well-known fact 